\title{
Emerging Needs and Viability of Telepsychiatry During and Post COVID-19 Era: A Literature Review
}

Jayasudha Gude ${ }^{1}$, Rashmi V. Subhedar ${ }^{2}$, Michelle H. Zhang ${ }^{3}$, Pratik Jain ${ }^{4}$, Jatminderpal Bhela ${ }^{5}$, Fariha Bangash $^{4}$, Nikhila Veluri ${ }^{6}$, Ya-Ching Hsieh ${ }^{7}$, Batool Z. Sheikh ${ }^{8,9}$, Mansi R. Shah ${ }^{10}$, Zeeshan Mansuri ${ }^{11}$, Kapil Aedma ${ }^{12}$, Urvish K. Patel ${ }^{13}$, Tapan Parikh ${ }^{14}$

1. Psychiatry, Northwell Health, Zucker Hillside Hospital, New York, USA 2. Family Medicine, Mc Master University, Hamilton, CAN 3. Psychological \& Brain Sciences and Biology, Johns Hopkins University, Baltimore, USA 4. Psychiatry, State University of New York Upstate Medical University, Syracuse, USA 5. Psychiatry, Case Western Reserve University/Metrohealth system, Cleveland, USA 6. Psychiatry, American University of Integrative Science School of Medicine, St. Michael, BRB 7. Public Health, Icahn School of Medicine at Mount Sinai, New York, USA 8. Psychiatry, Dow University of Health Sciences, Karachi, PAK 9. Psychiatry, Brookdale University Hospital Medical Center, New York, USA 10. Psychiatry, The Wright Center for Graduate Medical Education, Scranton, USA 11. Psychiatry, Boston Children's Hospital/Harvard Medical School, Boston, USA 12. Psychiatry, Unity Point, Peoria, USA 13. Public Health and Neurology, Icahn School of Medicine at Mount Sinai, New York, USA 14. Psychiatry, Northwestern University Feinberg School of Medicine, Chicago, USA

Corresponding author: Jayasudha Gude, pavjayt@gmail.com

Review began 07/12/2021 Review ended 08/06/2021 Published 08/07/2021

\section{() Copyright 2021}

Gude et al. This is an open access article distributed under the terms of the Creative Commons Attribution License CC-BY 4.0., which permits unrestricted use, distribution, and reproduction in any medium, provided the original author and source are credited.

\begin{abstract}
The coronavirus disease 2019 (COVID-19) pandemic has resulted in nationwide stay-at-home orders in an effort to slow the spread severely impacting the healthcare sector. Telepsychiatry provides a platform bridging the gap through advanced technologies connecting mental health providers and patients who need their services, overcoming previous barriers of great distances, lack of transportation, and even time constraints. The most obvious benefit is increased accessibility to mental healthcare, especially in underserved and remote areas where there is no easy access for in-person care. It is important to note that benefits are not limited to patients, but also allow clinicians greater flexibility in scheduling and reduced practice overhead costs, both of which aid with physician burnout and burden. Telepsychiatry during COVID-19 provides its own unique advantages over in-person visits. The risk of exposure to healthcare workers and patients receiving care is reduced, allowing immunocompromised patients to receive muchneeded psychiatric care. Without the need to meet in person, self-isolating psychiatrists can still provide care, decreasing strain on their co-workers. Although telepsychiatry is relatively new, it has already exhibited considerable success in its effectiveness at treating psychiatric conditions and widespread corollary benefits. Telepsychiatric consults may be carried out synchronously and asynchronously, each having benefits and setbacks. Different mobile application interventions have been explored, which are available for the purpose of both monitoring/assessing patients and/or providing treatment. The scope of conditions these applications address is broad, from anxiety disorders to schizophrenia to depression. As promising and beneficial telepsychiatry may seem, it is necessary to recognize that building the program can be challenging. It involves adapting to new methods in medicine. We highlighted barriers to general telepsychiatry, the most prominent being technological literacy of both physician and patient, and possible negative effects of eliminating the in-person patient-doctor interaction.
\end{abstract}

Categories: Psychiatry, Quality Improvement, Healthcare Technology

Keywords: tele psychiatry, covid 19, technology, viability of telepsychiatry, tele mental health, virtual clinics, communication

\section{Introduction And Background}

The recent coronavirus disease 2019 (COVID-19) pandemic has resulted in nationwide stay-at-home orders in an effort to slow the spread of the disease severely impacting many industries, including the healthcare sector [1]. As hospitals and healthcare providers pause non-emergency services and elective procedures, many patients are unable to receive care. In fact, $45 \%$ of U.S. adults reported they or someone in their household had deferred medical care due to the coronavirus pandemic [2]. Although the lack of these services may seem insignificant given their non-emergent status, they can still prove detrimental to an individual's well-being, especially when it comes to mental health. With patients being unable to see their psychiatrists for in-person sessions, it is imperative that alternative methods be explored in an attempt to bypass this obstacle.

As the prevalence of mental health disorders continues to increase among young adults, there is an imminent need for new and innovative ways to meet the populations' demands of effective delivery of psychiatric care [3]. In addition to the challenges introduced by COVID-19, there is an existing disparity regarding access to healthcare; 3.6 million Americans are unable to receive medical care due to a lack of 
transportation [4]. Telepsychiatry offers a prospective solution to all the aforementioned problems, promising a delivery method that is not only much easier to access but can adapt to match the demand whilst abiding by social distancing policies in place [5].

Telepsychiatry provides a virtual platform for the matching and communication between mental health providers and the patients who need their services, overcoming previous barriers of great distances, lack of transportation, and even time constraints. Many mental health conditions require outpatient follow-up and medical management. Given that, telepsychiatry has the potential to increase access to care while improving waiting times and reducing costs and the need for hospitalization [6].

This review examines the methods and limitations of telepsychiatry that are currently available and provides valuable insight into the outcomes of populations that are currently being implemented in telepsychiatry. It is important to note that telepsychiatry is not a cure-all solution. Despite the encouraging benefits, there are many questions to be considered, such as: Will the patient feel as connected with the provider as in-person visits? Can the same trust and emotional bond be forged over a virtual session? Psychiatry is different from other medical specialities where treatment is often a prescription or a one-time procedure. Ninety percent of the diagnosis and fifty percent of treatment involve direct communication between patient and psychiatrist, so it is imperative to address how telepsychiatry may modify or change the physician-patient relationship.

\section{Review}

With the COVID-19 pandemic came a dramatic shift of the U.S. healthcare system as traditional medicine transitioned from in-person visits to telemedicine instead. Without a vaccine or standardized effective treatment options, social distancing procedures and stay-at-home orders have become the primary forms of intervention. Given that, clinicians, healthcare workers, and insurers alike have been forced to adapt rapidly in order to provide an alternative to in-person care, turning to telemedicine. This surge in telemedicine has largely been focused on triage screening patients, much of which has been related to physical symptoms pertaining to COVID-19 [7,8]. What has been neglected amidst this pandemic, though, is the delivery and availability of mental healthcare. Whether it be the detrimental effects of social isolating, the panic that comes from losing one's job in a period of economic instability, or simply the stress that comes from living during such uncertain times, it is clear that mental health is more important than ever. During this viral outbreak, there has been a huge surge in symptoms of depression, anxiety, insomnia, and acute stress, whether it be healthcare providers or the general public [9-11]. As the prevalence of mental health disorders continues to increase at a startling rate, it is pertinent to turn to telepsychiatry as a means of increasing access to mental healthcare.

Before diving into the benefits, limitations, and methods of implementation of telepsychiatry, it is important to gain a thorough understanding and definition of telepsychiatry (Table 1). Specifically, what makes it different from telemedicine? Telemedicine is described as the remote assessment, diagnosis, and treatment of patients through the use of telecommunication audiovisual technology. This includes, but is not limited to, consultations over the phone, video calls or text messaging, digital transmission of medical imaging, and remote diagnoses. Telepsychiatry is a specific application of telemedicine within the speciality of psychiatry and involves making psychiatric diagnoses and administering psychiatric treatment or therapy through technological means. The history of telemedicine is long and extensive, with the first use of telemedicine being described in The Lancet in 1879 as the transmission of medical knowledge and conducting medical appointments through the telephone [12]. However, telepsychiatry was not documented until nearly a century later, in the 1950s, when the Nebraska Psychiatric Institute utilized videoconferencing for consultations, educational endeavours, and training for patients [13].

\section{Telemedicine \\ Remote assessment, diagnosis, and treatment of patients through the use of telecommunication audiovisual technology.}

Use of telemedicine was first described in The Lancet in 1879.

\section{Telepsychiatry}

Application of telemedicine within the specialty of psychiatry.

Related terms are telemental health and telepsychology.

Administration of psychiatric treatment or therapy via technological communication.

First use of videoconferencing in psychiatry was in the 1950s at the Nebraska Psychiatric Institute.

TABLE 1: Comparison of traditional telemedicine with telepsychiatry 


\section{Cureus}

extensive and far-reaching (Table 2). The increased accessibility to mental healthcare especially for those in underserved and remote areas seems to benefit maximally; additionally, transportation times and expenses are reduced along with base patient costs. These benefits result in lower attrition rates of patients, along with increased patient satisfaction with care [14-16]. It is important to note that benefits are not limited to patients, but also allow clinicians greater flexibility of scheduling and reduces practice overhead costs, both of which can aid with physician burnout and burden. Telepsychiatry during COVID-19 provides its own unique advantages over in-person visits. The risk of exposure to both healthcare workers and patients receiving care is greatly reduced, allowing immunocompromised patients to receive much-needed psychiatric care. Without the need to meet in person, self-isolating psychiatrists can still provide care, decreasing strain on their co-workers. Patients who have tested positive for coronavirus will still be able to meet with their psychiatrists.

Telepsychiatry Implementation and Potential Barriers and Benefits [14-16]

Barriers

Adapting to novel practice model and technology

Interruption of the in-person patient-doctor interaction

Liabilities and malpractice coverage concerns

Technology costs and security

Billing and reimbursement constraints

Out-of-state physician licensing and credentialing issues

Obtaining vital signs and necessary physical examinations, although the physical examination is less of a barrier in telepsychiatry compared to traditional telemedicine except for the evaluation of movement disorder or extrapyramidal side effects (EPS)

Concerns about patient confidentiality and security

Need for psychiatrists as well as patients to have a basic level of technological literacy; both parties will need to adapt to the technology

Patients with moderate to severe mental health illness might be reluctant to discuss their problems over teleconsultation services which can be a huge barrier.

\section{Benefits}

Accessibility to specialized mental health care in underserved and remote areas

Expand outreach, delivery, and efficiency of mental health practice

Reduction in transportation time and expenses

Low attrition rate of patients

Relieve physician burnout and increase well-being

Improved patient satisfaction

Improve clinical workflow and increase practice efficiency

Reduce practice overhead

Reduce patient costs

Reduce emergency room visits

Early detection allowing for preventative measures

Flexibility of scheduling

During CovID-19:

Minimize risk of exposure to healthcare workers, as well as patients receiving care

Immunocompromised patients will still be able to receive psychiatric care

Self-isolating psychiatrists can still provide care; prevents increasing strain on remaining co-workers

TABLE 2: Pros and cons of telepsychiatry

Within the branch of telepsychiatry, one can dissociate between synchronous and asynchronous telepsychiatry, each having its own benefits and setbacks. Synchronous telepsychiatry requires the presence of both the patient and the psychiatrist at the same time, engaging in real-time communication. 
Asynchronous telepsychiatry, on the other hand, can be thought of as the store-and-forward transmission of medical data, as well as clinical diagnosis, treatment, and recommendations [17,18]. For an extensive comparison of the relative benefits and setbacks, refer to Table 3. Given the varying advantages, we recommend that the use of either method be situational; it is a decision that should be made largely depending on the patient-provider relationship and what would optimize individual patient care.

Synchronous Telepsychiatry [17-24]

Consists of live videoconferencing and direct communication link between the psychiatrist and patient.

Allows for real-time live interaction and assessment.

Can gain additional details essential for care during the session, which is more efficient in making a clinical decision and providing advice during the interaction.

Real-time telepsychiatry provides timely care, especially in emergencies or urgent situations, and maintains the concept of the doctor-patient relationship by enabling a face-to-face analysis and treatment.

The doctor can see the patient and engage in conversation, much as they would in an office visit.

\section{Asynchronous Telepsychiatry [25-28]}

Consists of pre-recorded videos of psychiatrist that are then sent to the patient to be viewed on their own time.

Involves acquiring medical data and transmitting it to the psychiatrist at a convenient time for assessment offline.

Patients can get timely care without needing to travel beyond the location of their primary care providers.

Wait times for specialty care are lessened, especially in areas with shortages of psychiatrists.

The store-and-forward process can overcome language and cultural barriers.

Patients who are traveling or live in a different timezone can receive care without inconvenience.

The turnaround time to receive answers to patient concerns/questions may be longer than synchronous telepsychiatry.

\section{TABLE 3: Comparison of synchronous vs asynchronous telepsychiatry}

Although telepsychiatry is relatively new, it has already exhibited considerable success in both its effectiveness at treating psychiatric conditions as well as widespread corollary benefits. Although there are a few cases in which no significant improvement was seen between in-person psychiatry and telepsychiatry (five out of the 16 studies listed in Table 4), peripheral consequences such as decreased cost, better patientdoctor interactions, and higher satisfaction make telepsychiatry a viable, if not preferable choice to traditional in-person medicine. This, of course, only holds true for visits and disorders that do not necessitate physical examinations, which would be much more difficult to conduct virtually. Table 4 contains a comprehensive list of studies examining the effectiveness of telepsychiatry across multiple conditions, from depression and anxiety to dementia and post-traumatic illness, among others.

\begin{tabular}{|c|c|c|c|c|c|c|}
\hline $\begin{array}{l}\text { Author, } \\
\text { Country, } \\
\text { Year }\end{array}$ & Type of Study & $\begin{array}{l}\text { Psychiatric } \\
\text { condition } \\
\text { studied }\end{array}$ & $\begin{array}{l}\text { Sample } \\
\text { Size }\end{array}$ & $\begin{array}{l}\text { Outcomes } \\
\text { Measured }\end{array}$ & Results & $\begin{array}{l}\text { Interpretation } \\
\text { of study }\end{array}$ \\
\hline \multirow[t]{2}{*}{$\begin{array}{l}\text { Yellowlees } \\
\text { et al, USA } \\
2018 \text { [27] }\end{array}$} & $\begin{array}{l}\text { RCT } \\
\text { (Asynchronous } \\
\text { or ATP vs } \\
\text { Synchronous } \\
\text { or STP } \\
\text { Telepsychiatry) }\end{array}$ & $\begin{array}{l}\text { Depression, } \\
\text { anxiety and } \\
\text { substance } \\
\text { abuse }\end{array}$ & $\begin{array}{l}\text { ATP }=77, \\
\text { STP }=81\end{array}$ & $\begin{array}{l}\text { 1.Clinical outcome } \\
\text { using Clinical } \\
\text { global impressions } \\
\text { (CGI) } 2 \text {. } \\
\text { Satisfaction } 3 \text {. } \\
\text { economic data }\end{array}$ & $\begin{array}{l}\text { 1.Significant improvement in CGI from } \\
\text { baseline 2.Less average wait times (all for } \\
\text { ATP) 3.More efficient use of psychiatrist time } \\
\text { 4.Good teamwork along with PCP }\end{array}$ & $\begin{array}{l}\text { 1.Improved } \\
\text { patient } \\
\text { satisfaction } \\
\text { 2.Relieve } \\
\text { Physician } \\
\text { burnout and } \\
\text { well-being } \\
\text { 3.Decrease time } \\
\text { to essential } \\
\text { mental health } \\
\text { care }\end{array}$ \\
\hline & & & & $\begin{array}{l}\text { 1.Satisfaction with } \\
\text { treatment } 2 \text {. } \\
\text { Therapeutic }\end{array}$ & 1.High satisfaction with telepsychiatry 2.No & \\
\hline
\end{tabular}




\section{Cureus}

\begin{tabular}{|c|c|c|c|c|c|c|}
\hline $\begin{array}{l}\text { Farabee et } \\
\text { al, USA, } \\
2016 \text { [29] }\end{array}$ & $\begin{array}{l}\text { RCT (TP vs } \\
\text { TAU) }\end{array}$ & & $\mathrm{N}=104$ & $\begin{array}{l}\text { alliance } 3 . \\
\text { Medication } \\
\text { adherences } 4 . \\
\text { Psychological } \\
\text { functioning. }\end{array}$ & $\begin{array}{l}\text { significant group differences in medication } \\
\text { adherence or psychological functioning. } \\
\text { 3.Lower levels of the therapeutic alliance at } \\
\text { follow-up. }\end{array}$ & $\begin{array}{l}\text { 1.Improved } \\
\text { satisfaction with } \\
\text { telepsychiatry }\end{array}$ \\
\hline $\begin{array}{l}\text { Xiong et al, } \\
\text { USA } 2018 \\
\text { [30] }\end{array}$ & $\begin{array}{l}\text { RCT (STP vs } \\
\text { ATP) }\end{array}$ & $\begin{array}{l}\text { Dementia, } \\
\text { depression }\end{array}$ & $\begin{array}{l}\text { Total }= \\
43, \\
\text { ATP=22, } \\
\text { STP }=21\end{array}$ & $\begin{array}{l}\text { Clinical global } \\
\text { impressions (CGI) } \\
\text { severity at } 6 \text { month } \\
\text { and } 12 \text { month }\end{array}$ & $\begin{array}{l}\text { Significant improvement in CGI from } \\
\text { baseline to 6-month follow-up, regardless of } \\
\text { group assignment, Demonstrating the } \\
\text { acceptability, feasibility, and impact of both } \\
\text { forms of telepsychiatry in the Small nursing } \\
\text { facility (SNF) setting. }\end{array}$ & $\begin{array}{l}\text { 1.Telepsychiatry } \\
\text { is effective } \\
2 . I m p r o v e d \\
\text { satisfaction } \\
\text { rates with } \\
\text { telepsychiatry }\end{array}$ \\
\hline $\begin{array}{l}\text { Shulman et } \\
\text { al, USA, } \\
2017 \text { [31] }\end{array}$ & $\begin{array}{l}\text { RCT (TP vs } \\
\text { TAU) }\end{array}$ & & $\mathrm{N}=22$ & Visit adherence & $\begin{array}{l}\text { Not much difference in visit adherence } \\
\text { between the telepsychiatry and treatment- } \\
\text { as-usual groups (14\%, compared with 15\%). } \\
\text { A greater number of participants in the } \\
\text { telepsychiatry group reported less } \\
\text { subjective difficulty in keeping } \\
\text { appointments. }\end{array}$ & $\begin{array}{l}\text { 1.Increased } \\
\text { compliance with } \\
\text { telepsychiatry }\end{array}$ \\
\hline $\begin{array}{l}\text { O'reilly et al, } \\
\text { Canada, } \\
2007 \text { [32] }\end{array}$ & $\begin{array}{l}\text { RCT (TP vs } \\
\text { face to face) }\end{array}$ & & $\begin{array}{l}254 \text { (face } \\
\text { to face) } \\
241 \text { (TP) }\end{array}$ & $\begin{array}{l}\text { Distress from } \\
\text { psychiatric } \\
\text { symptoms using } \\
\text { the Brief Symptom } \\
\text { Inventory. }\end{array}$ & $\begin{array}{l}\text { Psychiatric consultation and follow-up } \\
\text { delivered by telepsychiatry produced clinical } \\
\text { outcomes that were equivalent to those } \\
\text { achieved when the service was provided } \\
\text { face to face }\end{array}$ & $\begin{array}{l}\text { Not much } \\
\text { difference } \\
\text { observed } \\
\text { between } \\
\text { telepsychiatry } \\
\text { and in-person } \\
\text { visits. }\end{array}$ \\
\hline $\begin{array}{l}\text { Zou et al, } \\
\text { USA, } 2016 \\
\text { [33] }\end{array}$ & $\begin{array}{l}\text { RCT (T-CSCT } \\
\text { vs TAU) }\end{array}$ & MDD & $\begin{array}{l}(\mathrm{N}= \\
190), T- \\
\text { CSCT }(\mathrm{n} \\
=97) \\
\text { TAU }(\mathrm{n}= \\
\text { 93) }\end{array}$ & $\begin{array}{l}\text { 17-item Hamilton } \\
\text { Depression Rating } \\
\text { Scale (HDRS } 17) ; \text { the } \\
\text { positive response } \\
\text { was defined as a } \geq \\
50 \% \text { decrease in } \\
\text { HDRS } 17 \text { score }\end{array}$ & $\begin{array}{l}\text { 1. Response and remission were significantly } \\
\text { greater for the } \mathrm{T} \text {-CSCT group compared to } \\
\text { the control group (odds ratio [OR] = } 3.9 \\
\text { [95\% } \mathrm{Cl}, 1.9 \text { to } 7.8 \text { ] and } 4.4[95 \% \mathrm{Cl}, 1.9 \text { to } \\
\text { 9.9], respectively). } 2 . \mathrm{T} \text {-CSCT group had } \\
\text { significantly greater improvement over time } \\
\text { in } \mathrm{HDRS} 17 \text { (F4,95 }=4.59, \mathrm{P}=.002 \text { ), CGI-S } \\
(\mathrm{F} 4,95=4.22, \mathrm{P}=.003 \text { ), and CGI-I (F4,95 = } \\
2.95, \mathrm{P}=.02) \text { scores. }\end{array}$ & $\begin{array}{l}\text { Improved } \\
\text { response rates } \\
\text { with } \\
\text { telepsychiatry }\end{array}$ \\
\hline $\begin{array}{l}\text { Chong et al, } \\
\text { USA, } 2012 \\
\text { [34] }\end{array}$ & $\begin{array}{l}\text { RCT (WEB vs } \\
\text { TAU) }\end{array}$ & Depression & $\begin{array}{l}\mathrm{N}=167, \\
\text { WEB }=80, \\
\mathrm{TAU}=87\end{array}$ & $\begin{array}{l}\text { 1.Acceptability } \\
\text { 2.visit satisfaction } \\
\text { 3. Antidepressant } \\
\text { use. 4.Feasibility }\end{array}$ & $\begin{array}{l}\text { 1.WEB patients did not differ in the } \\
\text { proportion of completed primary care versus } \\
\text { telepsychiatry appointments and rated their } \\
\text { working alliance with the psychiatrist and } \\
\text { their visit satisfaction significantly higher } \\
\text { than the TAU patients with their provider. } \\
\text { Significantly more WEB than TAU patients } \\
\text { used antidepressants. }\end{array}$ & $\begin{array}{l}\text { 1. Improved } \\
\text { acceptability, } \\
\text { feasibility, and } \\
\text { satisfaction } \\
\text { rates with } \\
\text { telepsychiatry }\end{array}$ \\
\hline $\begin{array}{l}\text { De Las } \\
\text { Cuevas et } \\
\text { al, Spain, } \\
2006[35]\end{array}$ & $\begin{array}{l}\text { RCT (VCTP vs } \\
\text { FTF) }\end{array}$ & & $N=140$ & $\begin{array}{l}\text { Clinical Global } \\
\text { Impressions- } \\
\text { Severity of IIIness } \\
\text { (CGI-S) and - } \\
\text { Improvement (CGI- } \\
\text { I) scales }\end{array}$ & $\begin{array}{l}\text { 1.Significant improvements were found on } \\
\text { the CGI and SCL-90- R Global Indexes } \\
\text { scores of both treatment groups, showing } \\
\text { clear clinical state improvement. } 2 \text {. } \\
\text { statistically significant differences were } \\
\text { observed when the efficacy of VCTP } \\
\text { treatment was compared to FTF psychiatric } \\
\text { treatment efficacy }\end{array}$ & $\begin{array}{l}\text { Higher response } \\
\text { rates and } \\
\text { satisfaction } \\
\text { rates in the } \\
\text { telepsychiatry } \\
\text { group. }\end{array}$ \\
\hline $\begin{array}{l}\text { Frueh et al, } \\
\text { USA, } 2007 \\
\text { [36] }\end{array}$ & RCT (TP vs SR) & $\begin{array}{l}\text { Post- } \\
\text { Traumatic } \\
\text { Stress } \\
\text { disorder }\end{array}$ & $\begin{array}{l}\mathrm{N}=38 \\
21-\mathrm{SR} \\
17-\mathrm{TP}\end{array}$ & $\begin{array}{l}\text { 12-item SER-TACP } \\
\text { (Therapist } \\
\text { adherence and } \\
\text { competence of } \\
\text { treatment) was } \\
\text { used to assess } \\
\text { adherence and } \\
\text { competence. }\end{array}$ & $\begin{array}{l}\text { Findings suggest that therapist competence } \\
\text { and adherence to cognitive-behavioural } \\
\text { therapy is similar whether the treatment is } \\
\text { delivered via TP or by traditional means, and } \\
\text { TP does not compromise therapists' ability } \\
\text { to effectively structure sessions or build } \\
\text { rapport with patients }\end{array}$ & $\begin{array}{l}\text { 1. Treatment } \\
\text { Adherence and } \\
\text { competence is } \\
\text { similar in } \\
\text { telepsychiatry } \\
\text { vs in-person } \\
\text { visits. } 2 \text {. } \\
\text { Improved } \\
\text { patient-doctor } \\
\text { interactions. }\end{array}$ \\
\hline & & & & & nd & \\
\hline
\end{tabular}




\section{Cureus}

\begin{tabular}{|c|c|c|c|c|c|c|}
\hline $\begin{array}{l}\text { Ruskin et al, } \\
\text { USA, } 2004 \\
\text { [37] }\end{array}$ & $\begin{array}{l}\text { RCT (TP vs in } \\
\text { person) }\end{array}$ & Depression & $\mathrm{N}=118$ & $\begin{array}{l}\text { 1.Treatment } \\
\text { response. } 2 . \\
\text { Treatment } \\
\text { adherence. } 3 . \\
\text { Patient } \\
\text { satisfaction. } 4 . \\
\text { Psychiatrist } \\
\text { satisfaction. } 5 . \\
\text { Resource } \\
\text { consumption or } \\
\text { cost effects. }\end{array}$ & $\begin{array}{l}\text { Beck Depression Inventory scores improved } \\
\text { over the treatment period and did not differ } \\
\text { between treatment groups. } 2 \text {. The two } \\
\text { groups were equally adherent to } \\
\text { appointments and medication treatment. No } \\
\text { between-group differences in dropout rates } \\
\text { or patients' ratings of satisfaction with } \\
\text { treatment were found. } 3 \text {. Telepsychiatry was } \\
\text { more expensive per treatment session, but } \\
\text { this difference disappeared if the costs of } \\
\text { psychiatrists' travel to remote clinics more } \\
\text { than } 22 \text { miles away from the medical center } \\
\text { were considered. }\end{array}$ & $\begin{array}{l}\text { 1. Not much } \\
\text { significant } \\
\text { between } \\
\text { treatment and in } \\
\text { person groups. } \\
\text { 2. Cost effective } \\
\text { for clinics far } \\
\text { away from the } \\
\text { medical } \\
\text { centers. }\end{array}$ \\
\hline $\begin{array}{l}\text { Moreno et } \\
\text { al, USA, } \\
2012 \text { [38] }\end{array}$ & $\begin{array}{l}\text { RCT (WEB vs } \\
\text { TAU) }\end{array}$ & Depression & $\mathrm{N}=167$ & $\begin{array}{l}\text { 1. Montgomery- } \\
\text { Åsberg Depression } \\
\text { Rating Scale by } \\
\text { clinician's blind to } \\
\text { treatment group } \\
\text { and 2. Self-ratings } \\
\text { on the nine-item } \\
\text { Patient Health } \\
\text { Questionnaire. } 3 \text {. } \\
\text { Quality of Life } \\
\text { Enjoyment and } \\
\text { Satisfaction } \\
\text { Questionnaire. } 4 \text {. } \\
\text { Sheehan Disability } \\
\text { Scale. }\end{array}$ & $\begin{array}{l}\text { 1. On all four measures, a significant } \\
\text { interaction of time by intervention favoring } \\
\text { the Webcam group was noted. } 2 \text {. Results } \\
\text { suggest that telepsychiatry delivered } \\
\text { through the internet utilizing commercially } \\
\text { available domestic Webcams and standard } \\
\text { internet and computer equipment is effective } \\
\text { and acceptable }\end{array}$ & $\begin{array}{l}\text { Telepsychiatry } \\
\text { was effective } \\
\text { and acceptable. }\end{array}$ \\
\hline $\begin{array}{l}\text { Bishop et al, } \\
\text { Canada, } \\
2002 \text { [39] }\end{array}$ & $\begin{array}{l}\text { RCT (VCTP vs } \\
\text { FTF) }\end{array}$ & & $\mathrm{N}=24$ & $\begin{array}{l}\text { Patient satisfaction } \\
\text { with the services } \\
\text { was assessed } \\
\text { using the Client } \\
\text { Satisfaction } \\
\text { Questionnaire } \\
\text { (CSQ-8), } \\
\text { completed four } \\
\text { months after the } \\
\text { initial consultation }\end{array}$ & $\begin{array}{l}\text { The mean scores were } 25.3 \text { in the FTF group } \\
\text { and } 21.6 \text { in the videoconferencing group. } \\
\text { Although there was a trend in favor of the } \\
\text { FTF service, the difference was not } \\
\text { significant }\end{array}$ & $\begin{array}{l}\text { Not much } \\
\text { significance in } \\
\text { the } \\
\text { telepsychiatry } \\
\text { vs face to face } \\
\text { visits groups. }\end{array}$ \\
\hline $\begin{array}{l}\text { Hulsbosch } \\
\text { et al, } \\
\text { Netherlands, } \\
2017 \text { [40] }\end{array}$ & $\begin{array}{l}\text { RCT (VCF vs } \\
\text { care as usual) }\end{array}$ & $\begin{array}{l}\text { Severe } \\
\text { mental } \\
\text { illness }\end{array}$ & $\begin{array}{l}\mathrm{N}=93, \\
\text { VCF } 47, \\
\text { care as } \\
\text { usual } \\
\text { (CAU) }= \\
46\end{array}$ & $\begin{array}{l}\text { Patient satisfaction } \\
\text { was the primary } \\
\text { outcome of the } \\
\text { study. The 'GGZ } \\
\text { Thermometer', a } \\
\text { validated Dutch } \\
\text { instrument for } \\
\text { assessing patient } \\
\text { satisfaction within } \\
\text { the mental health } \\
\text { care setting, } 11 \text { was } \\
\text { used }\end{array}$ & $\begin{array}{l}\text { A statistically significant time by treatment } \\
\text { interaction effect was found, where higher } \\
\text { degree of satisfaction was associated with } \\
\text { the patients in the VCF-group. }\end{array}$ & $\begin{array}{l}\text { Improves } \\
\text { patient } \\
\text { satisfaction in } \\
\text { the } \\
\text { telepsychiatry } \\
\text { group. }\end{array}$ \\
\hline \multirow[t]{2}{*}{$\begin{array}{l}\text { Maieritsch } \\
\text { et al, USA, } \\
2016 \text { [41] }\end{array}$} & \multirow[t]{2}{*}{$\begin{array}{l}\text { RCT (VCTP vs } \\
\text { in person) }\end{array}$} & $\begin{array}{l}\text { Post- } \\
\text { Traumatic } \\
\text { stress } \\
\text { disorder } \\
\text { (PTSD) }\end{array}$ & $\mathrm{N}=90$ & $\begin{array}{l}\text { Clinician- } \\
\text { administered PTSD } \\
\text { scale (CAPS) } \\
\text { scores }\end{array}$ & $\begin{array}{l}\text { A trend was observed which suggested that } \\
\text { Cognitive processing therapy (CPT) over } \\
\text { VTC may be equivalent to the treatment } \\
\text { delivered in person }\end{array}$ & $\begin{array}{l}\text { Not much } \\
\text { significance in } \\
\text { the } \\
\text { telepsychiatry } \\
\text { vs in person } \\
\text { group. }\end{array}$ \\
\hline & & & & $\begin{array}{l}\text { Outcomes were } \\
\text { diagnostic criteria } \\
\text { for ADHD and ODD } \\
\text { and role } \\
\text { performance on } \\
\text { the VADRS }\end{array}$ & $\begin{array}{l}\text { Children assigned to the telehealth service } \\
\text { model improved significantly more than } \\
\text { children in the augmented primary care arm }\end{array}$ & \\
\hline
\end{tabular}




\section{Cureus}

\begin{tabular}{|c|c|c|c|c|c|c|}
\hline $\begin{array}{l}\text { Myers et al, } \\
\text { USA, } 2015 \\
\text { [42] }\end{array}$ & $\begin{array}{l}\text { RCT (VCF vs } \\
\text { in-person) }\end{array}$ & $\begin{array}{l}\text { Attention } \\
\text { deficit } \\
\text { hyperactivity } \\
\text { disorder }\end{array}$ & $\mathrm{N}=223$ & $\begin{array}{l}\text { completed by } \\
\text { caregivers } \\
\text { (VADRS- } \\
\text { Caregivers) and } \\
\text { teachers (VADRS- } \\
\text { Teachers) and } \\
\text { impairment on the } \\
\text { Columbia } \\
\text { Impairment Scale- } \\
\text { Parent Version } \\
\text { (CIS-P) }\end{array}$ & $\begin{array}{l}\text { for VADRS-Caregiver criteria for inattention } \\
(x(2)[4]=19.47, p<.001) \text {, hyperactivity } \\
(x(2)[4]=11.91, p=.02), \text { combined ADHD } \\
(x(2)[4]=14.90, p=.005), \text { ODD }(x(2)[4]= \\
10.05, p=.04), \text { and VADRS-Caregiver role } \\
\text { performance }(x(2)[4]=12.40, p=.01) \text { and } \\
\text { CIS-P impairment }(x(2)[4]=20.52, p<.001) .\end{array}$ & $\begin{array}{l}\text { Improved } \\
\text { response rates } \\
\text { in telepsychiatry } \\
\text { group. }\end{array}$ \\
\hline $\begin{array}{l}\text { Hur et al, } \\
\text { Republic of } \\
\text { Korea, } 2017 \\
{[43]}\end{array}$ & $\begin{array}{l}\text { RCT - } \\
\text { scenario- } \\
\text { based CBT } \\
\text { mobile app } \\
\text { group, the } \\
\text { Todac Todac } \\
\text { group (TT } \\
\text { group) and an } \\
\text { app-based } \\
\text { mood charting } \\
\text { group (control } \\
\text { group) }\end{array}$ & $\begin{array}{l}\text { Depressive } \\
\text { disorder }\end{array}$ & $\mathrm{N}=34$ & $\begin{array}{l}\text { Outcomes } \\
\text { measured using } \\
\text { Dysfunctional } \\
\text { attitude score } \\
\text { (DAS), Beck's } \\
\text { depression } \\
\text { inventory } \\
\text { Scores(BDI-II) and } \\
\text { Situation } \\
\text { dependent trait } \\
\text { version of state } \\
\text { trait Anxiety } \\
\text { inventory (STAl- } \\
\text { X2) }\end{array}$ & $\begin{array}{l}\text { 1.After } 3 \text { weeks TT group showed lower DAS } \\
\text { scores and significantly lower STAI-X2 } \\
\text { scores compared to the control group. } \\
\text { 2.Both groups showed reduced BDI-II } \\
\text { scores. }\end{array}$ & $\begin{array}{l}\text { Mobile based } \\
\text { apps are helpful } \\
\text { in delivering } \\
\text { effective and } \\
\text { feasible } \\
\text { cognitive } \\
\text { therapy. }\end{array}$ \\
\hline
\end{tabular}

TABLE 4: Studies showing the effectiveness of telepsychiatry and telemedicine before the COVID-

\section{9 pandemic}

RCT - Randomized controlled trials; STP - Synchronous telepsychiatry (Synchronous refers to the delivery of health information in real-time); ATP Asynchronous telepsychiatry (Asynchronous refers to the "store-and-forward" technique, whereas a patient or physician collects medical history, images, and pathology reports and then sends it to a specialist physician for diagnostic and treatment expertise); T-CSCT - telepsychiatry-based culturally sensitive collaborative treatment; TP - Telepsychiatry; TAU - Treatment as usual; VCF - Videoconference; FTF - Face to face; SR - same room; WEB - Web-based tools; VCTP - Videoconference Telepsychiatry; CGI - Clinical global impressions; PCP - Primary care providers; HDRS - Hamilton depression rating scale; SCL-90 - Symptom Checklist-90; ADHD - Attention deficit hyperactivity disorder; ODD - oppositional defiant disorder; VADRS - Vanderbilt ADHD Rating Scale

Up until this point, we have discussed telepsychiatry in the context of virtual appointments and interactions that presumably take over phone or video calls, but with the advent of smartphones, mobile applications (apps) have become an area of interest. In Table 5, though, we have explored different mobile application interventions that are available for the sole purpose of both monitoring/assessing patients and/or providing treatment. The scope of conditions that these apps address is broad, ranging from anxiety disorders to schizophrenia to depression, etc. All studies reported high user satisfaction and a few even saw significant improvement in symptom reduction [44-51]. These findings, although preliminary, suggest a promising future for mobile applications that patients can use on their own time either independently or in conjunction with psychiatrist appointments and monitoring.

\begin{tabular}{|c|c|c|c|c|c|}
\hline $\begin{array}{l}\text { Author, } \\
\text { Country, } \\
\text { Year }\end{array}$ & Tools & Study Design & $\begin{array}{l}\text { Psychiatric } \\
\text { Condition } \\
\text { Studied }\end{array}$ & Description & Usefulness of Tool \\
\hline $\begin{array}{l}\text { De Sa \& } \\
\text { Carrico, } \\
\text { USA, } 2012 \\
{[44]}\end{array}$ & $\begin{array}{l}\text { Mobile App } \\
\text { Device: PDA }\end{array}$ & $\begin{array}{l}\text { Description of app } \\
\text { design process and } \\
\text { the results of a } \\
\text { qualitative exploratory } \\
\text { trial study, utilizing } \\
\text { direct observation, } \\
\text { interviews, and } \\
\text { questionnaires. } \\
\text { Participants } \\
\text { underwent } 1 \text { session. }\end{array}$ & $\begin{array}{l}\text { Children with } \\
\text { anxiety } \\
\text { disorders }\end{array}$ & $\begin{array}{l}\text { The existence of therapeutic } \\
\text { treatment tools for young } \\
\text { patients is low. Paper presents } \\
\text { mobile apps that aim to help } \\
\text { children ( } 5-14 \text { years of age) better } \\
\text { quantify their fears through the } \\
\text { use of drawing and components } \\
\text { that improve patient intractability } \\
\text { and understanding. The app was } \\
\text { also designed to better support } \\
\text { therapy procedures. }\end{array}$ & $\begin{array}{l}\text { Out of } 8 \text { children interviewed: } \\
3 \text { were pleased with the } \\
\text { experience, } 5 \text { found it easy to } \\
\text { use, } 7 \text { found it easier than the } \\
\text { paper equivalent. Both } \\
\text { patients and therapists were } \\
\text { satisfied and excited about } \\
\text { the app. }\end{array}$ \\
\hline
\end{tabular}




\section{Cureus}

\begin{tabular}{|c|c|c|c|c|c|}
\hline $\begin{array}{l}\text { liboshi et al., } \\
\text { Japan, } 2020 \\
\text { [45] }\end{array}$ & $\begin{array}{l}\text { VTC-administered } \\
\text { Montreal } \\
\text { Cognitive } \\
\text { Assessment Tool } \\
\text { (MoCA) }\end{array}$ & $\begin{array}{l}\text { Participants older than } \\
60 \text { years of age with } \\
\text { and without cognitive } \\
\text { impairment (mild } \\
\text { cognitive impairment } \\
\text { [MCI], dementia, and } \\
\text { healthy controls [HC]) } \\
\text { assessed using VTC } \\
\text { and face-to-face (FTF)- } \\
\text { administered MoCA at } \\
\text { an interval of }>2 \text { weeks } \\
\text { and }<3 \text { months. }\end{array}$ & $\begin{array}{l}\text { Mild cognitive } \\
\text { impairment } \\
\text { (MCl) and } \\
\text { dementia }\end{array}$ & $\begin{array}{l}\text { Despite the various potential } \\
\text { benefits of utilizing VTC- } \\
\text { administered MoCA to detect and } \\
\text { diagnose cognitive decline, not } \\
\text { many studies have examined the } \\
\text { reliability of such a tool, which } \\
\text { was the aim of this study. }\end{array}$ & $\begin{array}{l}\text { Intraclass correlation } \\
\text { coefficient (ICC) for the MoCA } \\
\text { was high in the entire sample } \\
\text { overall, and moderate to high } \\
\text { for the subgroups, indicating } \\
\text { good agreement between } \\
\text { VTC- and FTF-administration. } \\
\text { Participants also indicated } \\
\text { overall satisfaction with VTC- } \\
\text { administered MoCA. }\end{array}$ \\
\hline $\begin{array}{l}\text { Graham et } \\
\text { al., USA, } \\
2020 \text { [46] }\end{array}$ & $\begin{array}{l}\text { Intellicare: a suite } \\
\text { of mobile apps } \\
\text { providing a } \\
\text { library of } \\
\text { psychoeducation, } \\
\text { and administering } \\
\text { weekly symptom } \\
\text { assessment }\end{array}$ & $\begin{array}{l}\text { A two-arm randomized } \\
\text { clinical trial with } 146 \\
\text { patients, evaluating } \\
\text { the efficacy of a } \\
\text { mobile platform in } \\
\text { providing treatment for } \\
\text { depression and anxiety }\end{array}$ & $\begin{array}{l}\text { Depression } \\
\text { (positive on } \\
\text { Patient Health } \\
\text { Questionnaire- } \\
\text { 8; score>=10) } \\
\text { and anxiety } \\
\text { (Generalized } \\
\text { Anxiety } \\
\text { Disorder-7; } \\
\text { scores >= 8) }\end{array}$ & $\begin{array}{l}\text { Participants in intervention } \\
\text { conditions began IntelliCare } \\
\text { through onboarding calls with } \\
\text { their coach. Coaches managed } \\
\text { participants using an online } \\
\text { dashboard, containing info on } \\
\text { patient app use and their } \\
\text { symptom assessments. Primary } \\
\text { outcomes were assessed with } \\
\text { PHQ-9 and GAD-7 at baseline } \\
\text { and the follow-up assessments. }\end{array}$ & $\begin{array}{l}\text { Individuals in the intervention } \\
\text { condition had a greater } \\
\text { reduction in depression and } \\
\text { anxiety symptoms compared } \\
\text { with treatment-as-usual } \\
\text { participants. These changes } \\
\text { were also sustained over } 2 \\
\text { months. }\end{array}$ \\
\hline $\begin{array}{l}\text { Donker et } \\
\text { al., } \\
\text { Netherlands, } \\
2019[47]\end{array}$ & $\begin{array}{l}\text { ZeroPhobia, a } \\
\text { fully self-guided } \\
\text { virtual reality } \\
\text { equipment for } \\
\text { CBT }\end{array}$ & $\begin{array}{l}\text { Single-blind } \\
\text { randomized clinical } \\
\text { trial with } 193 \\
\text { participants with } \\
\text { acrophobia symptoms } \\
\text { to examine the } \\
\text { effectiveness of } \\
\text { ZeroPhobia }\end{array}$ & $\begin{array}{l}\text { Acrophobia } \\
\text { (score of at } \\
\text { least } 45.45 \text { on } \\
\text { Acrophobia } \\
\text { Questionnaire } \\
\text { (AQ)-Anxiety) }\end{array}$ & $\begin{array}{l}\text { Participants received } 6 \text { animated } \\
\text { CBT-based modules that took } \\
\text { between } 5-40 \text { minutes and were } \\
\text { asked to complete it within } 3 \\
\text { weeks. The primary outcome was } \\
\text { AQ scores. }\end{array}$ & $\begin{array}{l}\text { Intervention through } \\
\text { ZeroPhobia showed a } \\
\text { significant reduction in } \\
\text { acrophobia symptoms } \\
\text { compared with control on AQ } \\
\text { scores. The VR-CBT app } \\
\text { was also rated as user } \\
\text { friendly, showing the ease of } \\
\text { using technology-based } \\
\text { interventions. }\end{array}$ \\
\hline $\begin{array}{l}\text { Espie et al., } \\
\text { United } \\
\text { Kingdom, } \\
2019[48]\end{array}$ & $\begin{array}{l}\text { dCBT for } \\
\text { insomnia }\end{array}$ & $\begin{array}{l}\text { An online, 2-arm, } \\
\text { parallel-group } \\
\text { randomized trial } \\
\text { comparing dCBT for } \\
\text { insomnia with sleep } \\
\text { hygiene education } \\
\text { (SHE) evaluated } 1711 \\
\text { participants with self- } \\
\text { reported insomnia } \\
\text { symptoms }\end{array}$ & Insomnia & $\begin{array}{l}\text { dCBT was delivered to } \\
\text { participants using the web and/or } \\
\text { mobile channels along with } \\
\text { treatment as usual. SHE was a } \\
\text { website and a downloadable } \\
\text { booklet along with treatment as } \\
\text { usual. Primary outcomes were } \\
\text { scores on the Patient-Reported } \\
\text { Outcomes Measurement } \\
\text { Information System: Global } \\
\text { Health Scale, Warwick-Edinburgh } \\
\text { Mental Well-being Scale, and } \\
\text { Glasgow Sleep Impact Index. }\end{array}$ & $\begin{array}{l}\text { The use of dCBT was } \\
\text { associated with a small } \\
\text { improvement in functional } \\
\text { health, and psychological } \\
\text { well-being, and a large } \\
\text { improvement in sleep-related } \\
\text { quality of life. A large } \\
\text { improvement in insomnia was } \\
\text { the mediator of these } \\
\text { outcomes. Thus, we see } \\
\text { that dCBT is effective in } \\
\text { reducing insomnia symptoms, } \\
\text { which mediates the } \\
\text { aforementioned effects. }\end{array}$ \\
\hline $\begin{array}{l}\text { Ainsworth et } \\
\text { al., United } \\
\text { Kingdom, } \\
2013[49]\end{array}$ & $\begin{array}{l}\text { Android app } \\
\text { "ClinTouch" for } \\
\text { monitoring } \\
\text { schizophrenic } \\
\text { patients }\end{array}$ & $\begin{array}{l}\text { Randomized control } \\
\text { trial with } 24 \\
\text { participants comparing } \\
\text { two monitoring } \\
\text { systems for } \\
\text { schizophrenic patients } \\
\text { - one that is app- } \\
\text { based and one that } \\
\text { utilizes is short } \\
\text { messaging service- } \\
\text { based. }\end{array}$ & $\begin{array}{l}\text { Schizophrenia } \\
\text { (DSM-4) }\end{array}$ & $\begin{array}{l}\text { Schizophrenic participants were } \\
\text { randomly allocated to completing } \\
6 \text { days of assessment, involving } \\
\text { four sets of questions a day, } \\
\text { using the smartphone app or } \\
\text { SMS text-only implementation. A } \\
\text { 1-week break was given before } \\
\text { the alternative method was used } \\
\text { for } 6 \text { more days. Feedback was } \\
\text { obtained at the end of each } \\
\text { period of sampling. }\end{array}$ & $\begin{array}{l}\text { A significantly larger } \\
\text { proportion of data was } \\
\text { completed through the } \\
\text { smartphone application } \\
\text { compared to the short- } \\
\text { messaging implementation. } \\
\text { Most participants also } \\
\text { reported a preference for the } \\
\text { app, citing its ease of use. }\end{array}$ \\
\hline & $\begin{array}{l}\text { iPhone and } \\
\text { Android app } \\
\text { "WellWave" } \\
\text { designed to }\end{array}$ & $\begin{array}{l}\text { Pilot study that tested } \\
\text { the usability and } \\
\text { acceptability of } \\
\text { WellWave for adults }\end{array}$ & $\begin{array}{l}\text { A wide variety } \\
\text { of psychiatric } \\
\text { disorders }\end{array}$ & $\begin{array}{l}\text { Eleven volunteers, each with at } \\
\text { least one of the mentioned } \\
\text { psychiatric (4 schizophrenics) } \\
\text { completed an individual }\end{array}$ & $\begin{array}{l}\text { Participants used the app an } \\
\text { average of } 94 \% \text { of the days } \\
\text { and } 70 \% \text { of participants went } \\
\text { on a walk at least } 2 x \text { a week. }\end{array}$ \\
\hline
\end{tabular}




\section{Cureus}

\begin{tabular}{|c|c|c|c|c|c|}
\hline $\begin{array}{l}\text { al., USA, } \\
2015 \text { [50] }\end{array}$ & $\begin{array}{l}\text { facilitate self- } \\
\text { directed healthy } \\
\text { living and } \\
\text { psychiatric } \\
\text { recovery. }\end{array}$ & $\begin{array}{l}\text { diagnosed with } \\
\text { psychiatric conditions, } \\
\text { with the focus on } \\
\text { walking as a physical } \\
\text { exercise. }\end{array}$ & $\begin{array}{l}\text { (schizophrenia, } \\
\text { bipolar } \\
\text { disorder, or } \\
\text { MDD) }\end{array}$ & $\begin{array}{l}\text { WellWave training session before } \\
\text { completing a 4-week pilot. } 9 \\
\text { participants provided pretest and } \\
\text { posttest questionnaire data. }\end{array}$ & $\begin{array}{l}\text { All participants reported being } \\
\text { satisfied with the app, } \\
\text { reporting feelings of well- } \\
\text { being as well as practice } \\
\text { benefits. }\end{array}$ \\
\hline $\begin{array}{l}\text { Ben-Zeev et } \\
\text { al., USA, } \\
2014 \text { [51] }\end{array}$ & $\begin{array}{l}\text { Android app } \\
\text { "FOCUS" } \\
\text { designed for real- } \\
\text { time illness } \\
\text { management of } \\
\text { schizophrenic } \\
\text { patients }\end{array}$ & $\begin{array}{l}\text { Single-arm feasibility } \\
\text { trial examining the } \\
\text { efficacy and } \\
\text { acceptability of real- } \\
\text { time/real-place illness } \\
\text { management to } \\
\text { support schizophrenic } \\
\text { patients }\end{array}$ & $\begin{array}{l}\text { Schizophrenia } \\
\text { or } \\
\text { schizoaffective } \\
\text { disorder }\end{array}$ & $\begin{array}{l}33 \text { individuals w/schizophrenia or } \\
\text { schizoaffective disorders used } \\
\text { the FOCUS app for } 1 \text { month, with } \\
32 \text { users completing the trial } \\
\text { fully. }\end{array}$ & $\begin{array}{l}\text { Completers used FOCUS on } \\
86.5 \% \text { of days for an average } \\
\text { of } 5.2 x \text { a day. } 90 \% \text { of } \\
\text { participants rated the app as } \\
\text { highly acceptable and usable. } \\
\text { Study demonstrated the } \\
\text { feasibility, acceptability, and } \\
\text { preliminary efficacy of the } \\
\text { FOCUS intervention. }\end{array}$ \\
\hline
\end{tabular}

\section{TABLE 5: Tools utilized for telepsychiatry}

PDA - Personal digital assistants; VTC - Video teleconferencing; MoCA - Montreal Cognitive Assessment Tool; CBT - Cognitive behavioural therapy; VR-CBT - Virtual reality equipment for CBT; dCBT - Digital cognitive behavioural therapy; DSM-4 - Diagnostic and Statistical Manual of Mental Disorders 4th Edition; MDD - Major depressive disorder

Unfortunately, there is very limited literature on the current implementation of telepsychiatry during the coronavirus pandemic (Table 6 ). This is not a reflection of the inefficacy of telepsychiatry, though, but rather a reflection of its underutilization. This is a field of untapped potential that needs to be further explored and expanded upon, especially with the current climate of the pandemic. As promising and beneficial telepsychiatry may seem, though, it is necessary to recognize that no telemedicine program can be created overnight. There are challenges involved in adapting to this new method of medicine. Table 2 above highlights barriers to general telepsychiatry-the most prominent ones being the need for technological literacy on both the physician and patient end, as well the possible negative effects of eliminating the in-person patient-doctor interaction that is often used to build rapport. 


\section{Cureus}

Higher utilization rate of Telepsychiatry

\begin{tabular}{|c|c|c|c|c|c|c|}
\hline $\begin{array}{l}\text { Author, } \\
\text { Country, } \\
\text { Year }\end{array}$ & Type of Study & $\begin{array}{l}\text { Psychiatric } \\
\text { condition } \\
\text { studied }\end{array}$ & $\begin{array}{l}\text { Sample } \\
\text { Size }\end{array}$ & $\begin{array}{l}\text { Outcomes } \\
\text { Measured }\end{array}$ & Results & Interpretation of study \\
\hline $\begin{array}{l}\text { Zarghami } \\
\text { et al., } \\
\text { Iran, } 2020 \\
\text { [52] }\end{array}$ & $\begin{array}{l}\text { Report in which } \\
\text { video chat was used }\end{array}$ & $\begin{array}{l}\text { Insomnia } \\
\text { seen in } 24 \\
(29.3 \%) \\
\text { patients } \\
\text { and } \\
\text { adjustment } \\
\text { disorder in } \\
13(15.9 \%) \\
\text { patients }\end{array}$ & $\begin{array}{l}\text { Total(82) } \\
32 \\
\text { inpatient, } \\
50 \\
\text { outpatient, } \\
32 \text { male } \\
\text { and } 50 \\
\text { female }\end{array}$ & $\begin{array}{l}\text { Patient Health } \\
\text { Questionnaire-9 } \\
\text { (PHQ-9), } \\
\text { Generalized } \\
\text { Anxiety Disorder } \\
\text { Assessment } \\
\text { (GAD-7), and } \\
\text { Perceived Stress } \\
\text { Scale-14 (PSS } \\
\text { 14) } \\
\text { questionnaires }\end{array}$ & $\begin{array}{l}\text { Female and } \\
\text { hospitalized } \\
\text { patients } \\
\text { presented } \\
\text { significantly } \\
\text { more frequent } \\
\text { comorbidities } \\
\text { than males and } \\
\text { outpatients }\end{array}$ & $\begin{array}{l}\text { Telepsychiatry in the early stages of mental } \\
\text { problems during a catastrophic event like the } \\
\text { coronavirus pandemic, can be an efficient } \\
\text { instrument for the screening of } \\
\text { psychosomatic comorbidities, so that } \\
\text { pharmacological treatment (considering } \\
\text { possible drug interactions with COVID-19 } \\
\text { medications) and psychotherapeutic } \\
\text { intervention can be optimized by } \\
\text { psychiatrists. }\end{array}$ \\
\hline $\begin{array}{l}\text { Chen et } \\
\text { al, USA, } \\
2020 \text { [53] }\end{array}$ & $\begin{array}{l}\text { A review of key } \\
\text { changes that were } \\
\text { implemented during } \\
\text { COVID-19 with } \\
\text { regards to } \\
\text { psychiatric care, as } \\
\text { well as observations } \\
\text { of advantages and } \\
\text { limitations to } \\
\text { telepsychiatry }\end{array}$ & N/A & N/A & N/A & \multicolumn{2}{|c|}{$\begin{array}{l}\text { Biggest advantage of telepsychiatry during COVID-19 } \\
\text { pandemic is limiting viral transmission and reducing risk of } \\
\text { exposure. Clinical benefits include decreased no-show rates, } \\
\text { increased ease of scheduling and access to care, among other } \\
\text { advantages. The largest limitations included the lack of a } \\
\text { physical examination and mental status markers, loss of } \\
\text { intimacy, and exacerbated disparities for those who lack } \\
\text { access to technology. }\end{array}$} \\
\hline $\begin{array}{l}\text { Johns } \\
\text { Hopkins } \\
\text { Medicine, } \\
2020 \text { [54] }\end{array}$ & $\begin{array}{l}\text { Description of } \\
\text { transitions to } \\
\text { telepsychiatry at } \\
\text { Johns Hopkins } \\
\text { Hospital during the } \\
\text { COVID-19 pandemic }\end{array}$ & N/A & N/A & N/A & $\begin{array}{l}\text { Patients with } \\
\text { opioid use } \\
\text { disorder have } \\
\text { been able to } \\
\text { benefit from at- } \\
\text { home video } \\
\text { consultation } \\
\text { and } \\
\text { management } \\
\text { through } \\
\text { telepsychiatry. }\end{array}$ & $\begin{array}{l}\text { The efficacy and benefits of telepsychiatry } \\
\text { during the coronavirus pandemic have been } \\
\text { preliminarily demonstrated at a large scale } \\
\text { hospital (i.e., Johns Hopkins), implicating the } \\
\text { clinical benefits of transitioning to } \\
\text { telepsychiatry. }\end{array}$ \\
\hline
\end{tabular}

TABLE 6: Utilization of telepsychiatry during COVID-19 pandemic: utilization, advantages, and challenges

Specific to COVID-19, structured interviews with clinicians revealed problems that they ran into when transitioning to telepsychiatry (Table 7). These included decreased clinical data available to make an assessment or diagnosis and technological challenges (lack of reliable access to a computer, smartphone, or the internet) among other issues. 


\section{Cureus}

\begin{tabular}{|c|c|c|c|c|c|c|}
\hline Author/Year & $\begin{array}{l}\text { Type of } \\
\text { Study }\end{array}$ & $\begin{array}{l}\text { Psychiatric } \\
\text { condition } \\
\text { studied }\end{array}$ & $\begin{array}{l}\text { Sample } \\
\text { Sizes }\end{array}$ & Outcomes Measured & Results & Interpretation of study \\
\hline $\begin{array}{l}\text { Uscher- } \\
\text { Pines et al., } \\
\text { USA, } 2020 \\
{[55]}\end{array}$ & $\begin{array}{l}\text { Qualitatıve } \\
\text { Semi } \\
\text { structured } \\
\text { interview }\end{array}$ & $\mathrm{N} / \mathrm{A}$ & $\begin{array}{l}\text { N/A } 20 \\
\text { outpatient } \\
\text { psychiatrists } \\
\text { from } 5 \text { US } \\
\text { states semi } \\
\text { structured } \\
\text { interviews }\end{array}$ & $\mathrm{N} / \mathrm{A}$ & $\begin{array}{l}\text { Interview } \\
\text { summary } \\
\text { Matrix } \\
\text { analysis }\end{array}$ & $\begin{array}{l}\text { 1. Challenges affecting the quality of provider- } \\
\text { patient interactions } \quad \text { 2. Decreased clinical } \\
\text { data for assessment, } \quad \text { 3. Diminished patient } \\
\text { privacy } 4 \text {. Increased distractions in the patient's } \\
\text { home setting. 5.Disadvantaged patients lacked } \\
\text { reliable access to a computer, smartphone, and } \\
\text { the internet. }\end{array}$ \\
\hline $\begin{array}{l}\text { Uscher- } \\
\text { Pines et al., } \\
\text { USA, } 2020 \\
{[56]}\end{array}$ & $\begin{array}{l}\text { Semi } \\
\text { structured } \\
\text { interview }\end{array}$ & OUD & $\begin{array}{l}18 \text { clinicians } \\
\text { from } 10 \\
\text { states }\end{array}$ & $\begin{array}{l}\text { Changes included } \\
\text { waiving urine toxicology } \\
\text { screening, sending } \\
\text { patients home with a } \\
\text { larger supply of OUD } \\
\text { medications, and } \\
\text { requiring fewer visits }\end{array}$ & $\begin{array}{l}\text { Interview } \\
\text { summary }\end{array}$ & $\begin{array}{l}\text { 1. Less structure and accountability, 2. Less } \\
\text { information to inform clinical decision-making, } 3 . \\
\text { Challenges in establishing a connection, } 4 . \\
\text { Technological challenges, and shorter visits. }\end{array}$ \\
\hline
\end{tabular}

TABLE 7: Challenges in maintaining telepsychiatry after COVID-19 pandemic

OUD - Opioid use disorder

Given this, it is necessary to implement some advanced directives that will smoothly aid the shift toward telepsychiatry. We provide a few recommendations below. First and foremost, it will be crucial to evaluate telehealth competency among psychiatrists before establishing a standard for telepsychiatry training, in addition to creating frameworks for virtual psychiatric practice. This first step will provide a stable foundation for the entire psychiatric field to promote quality and regulated care.

\section{Advance Directives}

The following recommendations may be beneficial in improving telepsychiatry and telehealth services. Conducting and evaluating current telehealth competency among psychiatrists and physicians to promote quality care across practices [57]. Evaluate and improve current frameworks for technological competency and use in psychiatry [58]. Establish standardized training for psychiatrists who are currently practicing in the field extend telepsychiatry training to include undergraduate medical education for early training and introduction to telepsychiatry [59]. Provide patients with technological training to ensure that they have the digital literacy to use these virtual services and apps [60,61]. Work with social workers to ensure that patients in remote areas have consistent access to technological resources.

\section{Conclusions}

Overall, the use of telemedicine to provide medical care is not novel, but the COVID-19 pandemic has forced the US healthcare system to promptly shift to telehealth, whether or not it was ready to do so. When looking at this shift to telemedicine, some specialities have been focused on greater than others, and psychiatry is one field that has been overlooked. This current review examined the feasibility, efficacy, and likelihood of successful implementation of telepsychiatry both during the pandemic and beyond. The advantageous benefits of telepsychiatry, whether it be used in conjunction with mobile smartphone applications or synchronous/asynchronous, are widespread and many. The potential of using virtual medicine to change the way the psychiatric field is structured is unbounded, although this transition is not without barriers or difficulties. To address these issues, preemptive steps must be taken to standardize practice and thoroughly prepare healthcare providers. With careful planning and collaborative teamwork, telepsychiatry implementation can provide practical and satisfactory delivery of mental healthcare, benefitting both patients and clinicians.

\section{Appendices}

Jayasudha Gude and Rashmi V. Subhedar work as equal authors.

Authors' contributions: Conceptualization: Jayasudha Gude and Rashmi V. Subhedar; Acquisition of literature: Michelle H. Zhang, Pratik Jain, Jatminderpal Bhela; Formal investigation: Jayasudha 
Gude, Rashmi V. Subhedar; Writing - original draft preparation:Jayasudha Gude, Rashmi V. Subhedar, Fariha Bangash, Nikhila Veluri, Ya-Ching Hsieh; Writing - review, critical feedback, and editing: Batool Z. Sheikh, Mansi R. Shah, Kapil Aedma, Urvish K. Patel, Tapan Parikh; Supervision: Kapil Aedma,Tapan Parikh.

\section{Additional Information \\ Disclosures}

Conflicts of interest: In compliance with the ICMJE uniform disclosure form, all authors declare the following: Payment/services info: All authors have declared that no financial support was received from any organization for the submitted work. Financial relationships: All authors have declared that they have no financial relationships at present or within the previous three years with any organizations that might have an interest in the submitted work. Other relationships: All authors have declared that there are no other relationships or activities that could appear to have influenced the submitted work.

\section{References}

1. Cutler D: How will COVID-19 affect the health care economy? . JAMA Health Forum. 2020, 1:e200419. 10.1001/jamahealthforum.2020.0419

2. KFF Health Tracking Poll - May 2020 . (2020). Accessed: May 27th, 2020: https://www.kff.org/reportsection/kff-health-tracking-poll-may-2020-health-and-economic-impacts/.

3. Mental health issues increased significantly in young adults over last decade . (2019). Accessed: March 15, 2019: https://www.sciencedaily.com/releases/2019/03/190315110908.htm..

4. Social determinants of health series: Transportation and the role of hospitals. Health Research \& Educational Trust, Chicago, IL; 2017. https://www.aha.org/system/files/hpoe/Reports-HPOE/2017/sdohtransportation-role-of-hospitals.pdf.

5. Patel UK, Malik P, DeMasi M, Lunagariya A, Jani VB: Multidisciplinary approach and outcomes of teleneurology: a review. Cureus. 2019, 11:e4410. 10.7759/cureus.4410

6. Salmoiraghi A, Hussain S: A systematic review of the use of telepsychiatry in acute settings . J Psychiatr Pract. 2015, 21:389-93. 10.1097/PRA.0000000000000103

7. Lee MR, Ruehmann LL, Dively-White MT, Mathsen RL, Johnston JM, Jensen TB: Telehealth triage nursing and telemedicine: joining forces for improved care delivery in a primary care setting. Austin J health care. 2017, 4(1):1036.

8. Korber B, Fischer WM, Gnanakaran S, et al.: Tracking Changes in SARS-CoV-2 Spike: Evidence that D614G Increases Infectivity of the COVID-19 Virus. Cell. 2020, 182:812-27. 10.1016/j.cell.2020.06.043

9. Rossi R, Socci V, Pacitti F, Di Lorenzo G, Di Marco A, Siracusano A, Rossi A: Mental health outcomes among frontline and second-line health care workers during the coronavirus disease 2019 (COVID-19) pandemic in Italy. JAMA Netw Open. 2020, 3:e2010185. 10.1001/jamanetworkopen.2020.10185

10. Ettman CK, Abdalla SM, Cohen GH, Sampson L, Vivier PM, Galea S: Prevalence of depression symptoms in US adults before and during the COVID-19 pandemic. JAMA Netw Open. 2020, 3:e2019686. 10.1001/jamanetworkopen.2020.19686

11. Shi L, Lu ZA, Que JY, et al.: Prevalence of and risk factors associated with mental health symptoms among the general population in China during the coronavirus disease 2019 pandemic. JAMA Netw Open. 2020, 3:e2014053. 10.1001/jamanetworkopen.2020.14053

12. Aronson SH: The Lancet on the telephone 1876-1975 . Medical History. 1977, 21(1):69-87. 10.1017\%2Fs0025727300037182

13. Doarn CR: Telemedicine and psychiatry-a natural match. Mhealth. 2018, 4:60. 10.21037/mhealth.2018.12.04

14. Bashshur RL, Shannon GW, Bashshur N, Yellowlees PM: The empirical evidence for telemedicine interventions in mental disorders. Telemed J E Health. 2016, 22:87-113. 10.1089/tmj.2015.0206

15. Polinski JM, Barker T, Gagliano N, Sussman A, Brennan TA, Shrank WH: Patients' satisfaction with and preference for telehealth visits. J Gen Intern Med. 2016, 31:269-75. 10.1007/s11606-015-3489-X

16. Patient experience - ortholive telehealth application . (2018). Accessed: September 27, 2020: https://www.ortholive.com/blog/patient-experience-ortholive-telehealth-application/.

17. Telemedicine: 5 questions asked and answered. (2016). Accessed: June 13th, 2016: https://blogs.va.gov/VAntage/28397/telemedicine/.

18. Telemedicine and Telehealth. (2020). Accessed: September 24, 2020: https://www.healthit.gov/topic/healthit-health-care-settings/telemedicine-and-telehealth.

19. Nesbitt TS: The evolution of telehealth: where have we been and where are we going? . Institute of Medicine. The National Academies Press, Washington (DC); 2012.

20. Preston J, Brown FW, Hartley B: Using telemedicine to improve health care in distant areas. Hosp Community Psychiatry. 1992, 43:25-32. 10.1176/ps.43.1.25

21. Estimated cost savings. (2020). Accessed: September 27, 2020: https://www.ohsu.edu/telemedicine/estimated-cost-savings.

22. Who bears the costs and receives the benefits of telehealth? . (2017). Accessed: September 27, 2020: https://prognocis.com/who-bears-the-costs-and-receives-the-benefits-of-telehealth/.

23. The two forms of telemedicine: synchronous vs. asynchronous . (2019). Accessed: September 10, 2019: https://blog.cureatr.com/two-forms-telemedicine-synchronous-vs-asynchronous.

24. Wilson LS, Maeder AJ: Recent directions in telemedicine: review of trends in research and practice . Healthc Inform Res. 2015, 21:213-22. 10.4258/hir.2015.21.4.213

25. 8 Advantages and benefits of telehealth. (2019). Accessed: August 22, 2019: https://blog.cureatr.com/8advantages-benefits-telehealth.

26. Store-and-forward (asynchronous). (2020). Accessed: December 26, 2020: https://www.cchpca.org/what-is- 
telehealth/?category=store-and-forward.

27. Yellowlees P, Burke Parish M, González Á, et al.: Asynchronous telepsychiatry: a component of stepped integrated care. Telemed J E Health. 2018, 24:375-8. 10.1089/tmj.2017.0103

28. Store-and-forward telemedicine services expand connected health. (2018). Accessed: December 26, 2020: https://mhealthintelligence.com/features/store-and-forward-telemedicine-services-expand-connectedhealth.

29. Farabee D, Calhoun S, Veliz R: An experimental comparison of telepsychiatry and conventional psychiatry for parolees. Psychiatr Serv. 2016, 67:562-5. 10.1176/appi.ps.201500025

30. Xiong GL, Iosif AM, Godwin HT, Khan M, Parish MB, Yellowlees P, Kahn D: A pilot randomized trial of asynchronous and synchronous telepsychiatry in skilled nursing facilities. J Am Med Dir Assoc. 2018, 19:461-2. 10.1016/.j.jamda.2018.02.007

31. Shulman M, John M, Kane JM: Home-based outpatient telepsychiatry to improve adherence with treatment appointments: a pilot study. Psychiatr Serv. 2017, 68:743-6. 10.1176/appi.ps.201600244

32. O'Reilly R, Bishop J, Maddox K, Hutchinson L, Fisman M, Takhar J: Is telepsychiatry equivalent to face-toface psychiatry? Results from a randomized controlled equivalence trial. Psychiatr Serv. 2007, 58:836-43. 10.1176/ps.2007.58.6.836

33. Zou L, Yeung A, Li C, et al.: Effects of meditative movements on major depressive disorder: a systematic review and meta-analysis of randomized controlled trials. J Clin Med. 2018, 7:195. 10.3390//cm7080195

34. Chong J, Moreno F: Feasibility and acceptability of clinic-based telepsychiatry for low-income Hispanic primary care patients. Telemed J E Health. 2012, 18:297-304. 10.1089/tmj.2011.0126

35. De Las Cuevas C, Arredondo MT, Cabrera MF, Sulzenbacher H, Meise U: Randomized clinical trial of telepsychiatry through videoconference versus face-to-face conventional psychiatric treatment. Telemed J E Health. 2006, 12:341-50. 10.1089/tmj.2006.12.341

36. Frueh BC, Monnier J, Grubaugh AL, Elhai JD, Yim E, Knapp R: Therapist adherence and competence with manualized cognitive-behavioral therapy for PTSD delivered via videoconferencing technology. Behav Modif. 2007, 31:856-66. 10.1177/0145445507302125

37. Ruskin PE, Silver-Aylaian M, Kling MA, et al.: Treatment outcomes in depression: comparison of remote treatment through telepsychiatry to in-person treatment. Am J Psychiatry. 2004, 161:1471-6. 10.1176/appi.ajp.161.8.1471

38. Moreno FA, Chong J, Dumbauld J, Humke M, Byreddy S: Use of standard webcam and internet equipment for telepsychiatry treatment of depression among underserved Hispanics. Psychiatr Serv. 2012, 63:1213-7. 10.1176/appi.ps.201100274

39. Bishop JE, O'Reilly RL, Maddox K, Hutchinson LJ: Client satisfaction in a feasibility study comparing faceto-face interviews with telepsychiatry. J Telemed Telecare. 2002, 8:217-21. 10.1258/135763302320272185

40. Hulsbosch AM, Nugter MA, Tamis P, Kroon H: Videoconferencing in a mental health service in The Netherlands: a randomized controlled trial on patient satisfaction and clinical outcomes for outpatients with severe mental illness. J Telemed Telecare. 2017, 23:513-20. 10.1177/1357633X16650096

41. Maieritsch KP, Smith TL, Hessinger JD, Ahearn EP, Eickhoff JC, Zhao Q: Randomized controlled equivalence trial comparing videoconference and in person delivery of cognitive processing therapy for PTSD. J Telemed Telecare. 2016, 22:238-43. 10.1177/1357633X15596109

42. Myers K, Vander Stoep A, Zhou C, McCarty CA, Katon W: Effectiveness of a telehealth service delivery model for treating attention-deficit/hyperactivity disorder: a community-based randomized controlled trial. J Am Acad Child Adolesc Psychiatry. 2015, 54:263-74. 10.1016/j.jaac.2015.01.009

43. Hur JW, Kim B, Park D, Choi SW: A scenario-based cognitive behavioral therapy mobile app to reduce dysfunctional beliefs in individuals with depression: a randomized controlled trial. Telemed J E Health. 2018, 24:710-6. 10.1089/tmj.2017.0214

44. de Sá M, Carriço L: Fear therapy for children: a mobile approach. . Proceedings of the 4th ACM SIGCHI symposium on engineering interactive computing systems. 2012, EICS '12:Pages 237-46. $10.1145 / 2305484.2305524$

45. Iiboshi K, Yoshida K, Yamaoka Y, et al.: A validation study of the remotely administered montreal cognitive assessment tool in the elderly Japanese population. Telemed J E Health. 2020, 26:920-8. 10.1089/tmj.2019.0134

46. Graham AK, Greene CJ, Kwasny MJ, Kaiser SM, Lieponis P, Powell T, Mohr DC: Coached mobile app platform for the treatment of depression and anxiety among primary care patients: a randomized clinical trial. JAMA Psychiatry. 2020, 77:906-14. 10.1001/jamapsychiatry.2020.1011

47. Donker T, Cornelisz I, van Klaveren C, van Straten A, Carlbring P, Cuijpers P, van Gelder JL: Effectiveness of self-guided app-based virtual reality cognitive behavior therapy for acrophobia: a randomized clinical trial. JAMA Psychiatry. 2019, 76:682-90. 10.1001/jamapsychiatry.2019.0219

48. Espie CA, Emsley R, Kyle SD, et al.: Effect of digital cognitive behavioral therapy for insomnia on health, psychological well-being, and sleep-related quality of life: a randomized clinical trial. JAMA Psychiatry. 2019, 76:21-30.10.1001/jamapsychiatry.2018.2745

49. Ainsworth J, Palmier-Claus JE, Machin M, et al.: A comparison of two delivery modalities of a mobile phonebased assessment for serious mental illness: native smartphone application vs text-messaging only implementations. J Med Internet Res. 2013, 15:e60. 10.2196/jmir.2328

50. Macias C, Panch T, Hicks YM, Scolnick JS, Weene DL, Öngür D, Cohen BM: Using smartphone apps to promote psychiatric and physical well-being. Psychiatr Q. 2015, 86:505-19. 10.1007/s11126-015-9337-7

51. Ben-Zeev D, Brenner CJ, Begale M, Duffecy J, Mohr DC, Mueser KT: Feasibility, acceptability, and preliminary efficacy of a smartphone intervention for schizophrenia. Schizophr Bull. 2014, 40:1244-53. 10.1093/schbul/sbu033

52. Zarghami A, Farjam M, Fakhraei B, Hashemzadeh K, Yazdanpanah MH: A report of the telepsychiatric evaluation of SARS-CoV-2 patients. Telemed J E Health. 2020, 26:1461-5. 10.1089/tmj.2020.0125

53. Chen JA, Chung WJ, Young SK, et al.: COVID-19 and telepsychiatry: early outpatient experiences and implications for the future. Gen Hosp Psychiatry. 2020, 66:89-95. 10.1016/j.genhosppsych.2020.07.002

54. COVID-19 tip sheet: story ideas from Johns Hopkins . (2020). Accessed: October 11, 2020: 


\section{Cureus}

https://www.hopkinsmedicine.org/news/newsroom/news-releases/covid-19-tip-sheet-story-ideas-fromjohns-hopkins-4.

55. Uscher-Pines L, Sousa J, Raja P, Mehrotra A, Barnett ML, Huskamp HA: Suddenly becoming a "Virtual Doctor": experiences of psychiatrists transitioning to telemedicine during the COVID-19 pandemic. Psychiatr Serv. 2020, 71:1143-50. 10.1176/appi.ps.202000250

56. Uscher-Pines L, Sousa J, Raja P, Mehrotra A, Barnett M, Huskamp HA: Treatment of opioid use disorder during COVID-19: experiences of clinicians transitioning to telemedicine. J Subst Abuse Treat. 2020, 118:108124. 10.1016/j.jsat.2020.108124

57. Hilty DM, Maheu MM, Drude KP, Hertlein KM: The need to implement and evaluate telehealth competency frameworks to ensure quality care across behavioral health professions. Acad Psychiatry. 2018, 42:818-24. 10.1007/s40596-018-0992-5

58. Hilty D, Chan S, Torous J, Luo J, Boland R: A framework for competencies for the use of mobile technologies in psychiatry and medicine: scoping review. JMIR Mhealth Uhealth. 2020, 8:e12229. 10.2196/12229

59. Waseh S, Dicker AP: Telemedicine training in undergraduate medical education: mixed-methods review . JMIR Med Educ. 2019, 5:e12515. 10.2196/12515

60. Hoffman L, Wisniewski H, Hays R, et al.: Digital opportunities for outcomes in recovery services (DOORS): a pragmatic hands-on group approach toward increasing digital health and smartphone competencies, autonomy, relatedness, and alliance for those with serious mental illness. J Psychiatr Pract. 2020, 26:80-8. 10.1097/PRA.0000000000000450

61. Kichloo A, Albosta M, Dettloff K, et al.: Telemedicine, the current COVID-19 pandemic and the future: a narrative review and perspectives moving forward in the USA. Fam Med Community Health. 2020, 8:e000530. 10.1136/fmch-2020-000530 